\title{
Quality Education Accreditation of the United States and Vietnam's Management Model
}

\author{
Nguyen Duc Hanh \\ Correspondence: Nguyen Duc Hanh, Dai Nam University, Hanoi, Vietnam
}

Received: April 20, 2020 Accepted: May 18, 2020 Online Published: May 25, 2020

doi:10.5539/res.v12n2p79 URL: https://doi.org/10.5539/res.v12n2p79

\begin{abstract}
Accreditation is a solution for improving the quality of education in higher education institutions. Quality accreditation plays a dominant role that supports quality assurance management in the higher education system. The accreditation frameworks and external quality assurance are different between countries. The United States started quality accreditation very early, so it has a robust educational quality accreditation system, excellent support for the development of higher education institutions. Vietnam has only begun to conduct quality accreditation in recent years. At present, there are still some differences between Vietnam and the United States in quality management activities, but education quality accreditation of Vietnam is approximately similar the United States and carried out in three models: the model of central control of quality assurance of state; model of quality assurance combining between state control with the market competition; and model in which the state primarily leave responsibility for quality assurance to self-accrediting universities.
\end{abstract}

Keywords: accreditation, higher education, quality education, autonomous university, quality assurance

\section{Introduction}

Today, the higher education system has identified quality accreditation as an essential factor in improving the quality and agreement with the increased size, complexity, and diversity of the higher education field. In response to the period of international integration of higher education, United Nations Educational Scientific and Cultural Organization (UNESCO) and the Organization for Economic Co-operation and Development (OECD) has encouraged governments and stakeholders should be responsible for quality accreditation activities. There are some related elements to explain the importance of the quality assurance: (1) Due to the decline in academic standards of higher education; (2) Key stakeholders such as enterprises, employers units, no longer believe in the quality management capacity of higher education institutions to respond the output standards; (3) Budget constraints result in stopping or reducing government funding for each student and the pressure to save but must increase the efficiency in public spending; (4) There is increasing competition between higher education institutions for enrollment, student employment, and employers units, etc. (Damme, 2002).

Accreditation can see as "a complementary measure in a quality assurance system, and the starting is the need to maintain and improve good quality in higher education institutions. Evaluations will normally assess to what extent programs or institutions are meeting the levels of the quality set before. In contrast, accreditation passes a verdict on whether programs, degrees, or institutions meet certain outside standards or requirements. The specific object of accreditation is to certify a defined standard of quality, although it may embed in a larger evaluation process with multiple aims..." (European Network for Quality Assurance, 2001). Accreditation can play a more or less dominant role in the field of different measures that aim at monitoring, steering, recognizing, and quality assuring higher education (Eaton, 2003).

In 2007, Vietnam began to promulgate official regulations on educational quality accreditation. Thus, this study mainly reviews and analyzes the quality education accreditation models of the United States and Vietnam. Such as in terms of viewpoints, aims, functions, characteristics, importance, possible actions, types and the criteria of accreditation, tasks importance of higher education quality accreditation, etc. as well as management model, to advise on quality assurance activities in Vietnam.

\section{Study Contents and Discussion}

\subsection{Higher Education Accreditation - Each Nation's Perspective}

Aims of accreditation:

In US, generally, the quality accreditation is purposeful: (1) Reassure the society that the institution has met accordingly 
standards and criteria of accreditations issued by a competent authority; (2) Promoting institutional engagement with issues of educational effectiveness, developing and sharing practices in assessing and improving the teaching and learning process; (3) Applying standards to review and improve educational quality and institutional performance through ongoing research and feedback; (4) Expand in bodies on an "evidence culture", where indicators of performance and data collected to support for decision-making, planning, and improvement (Parekh, 2000), (Kymlicka \& Patten, 2003); (5) Build evaluation systems are adaptive to institutional context and purposes, support to reduce the burden and cost of accreditation; (6) Promoting the exchange between public and independent organizations that improved institutional execution, effective education and the peer review process (Western Association of Schools and Colleges, 2001).

Meanwhile, in Vietnam, the objectives of educational quality accreditation are: (1) Ensure and improve the quality of education; (2) Confirmation of the level of the educational institution or training program's fulfillment in each period; (3) As a basis for educational institutions to explain to owners, competent state agencies, related parties and society about the status of educational quality; (4) As a basis for students to select educational institutions, training programs, for employers to recruit human resources (Vietnam law library [VLL], 2005).

\section{Accreditation importance:}

In the US, quality accreditation is essential for the following reasons:(1) Accreditation is the main activity to ensure the quality of learners and provide high-quality human resources for society; (2) There are opportunities to be funded by state funds because accreditation is a prerequisite for being able to receive federal funding; (3) Accreditation is essential for students to transfer courses and programs between universities (Eaton, 2006).

In Vietnam, the role of quality accreditation is also critical because: (1) Quality accreditation of universities allows universities to review their entire activities systematically from which to adjust their activities to a certain standard; (2) Quality accreditation helps universities guide and define quality standards for each activity; (3) Educational quality accreditation is a guarantee statement to stakeholders for quality of organizations; (4) Quality education accreditation creates the premise for building a quality culture for educational institutions (Nguyen, 2019).

Quality educational accreditation in the US and Vietnam includes organization accreditation and specialized accreditation (or program accreditation) within an organization.

\subsection{Quality Education Accreditation of the United States - Vietnam's Management Model}

This section will analyze the models of higher education accreditation management in the US and Vietnam, include the mission, the operation, the recognition, teaching, faculty, infrastructure, student services, finances, etc.

\section{+ About the mission:}

In the US, quality accreditation is essential to demonstrate society's belief in education institutions, in maintaining standards, improving efficiency, and improving the quality of teaching and learning. It is the basis to ensure that the accredited organization complies with the criteria of a common set of standards (Koenig et al. 2004).

In Vietnam, the mission of accrediting higher education is to ensure social and stakeholders' quality of training and continuous improvement to raise the effectiveness of an educational institution, and affirm that educational institution has met accreditation standards (Nguyen, 2019).

+ About governance responsibility:

American quality accreditation has been around for more than 100 years, stemming from the government's interest to serve the good of society. (Eaton, 2006).

In Vietnam, accreditation is an operation performed by (1) Universities are responsible for ensuring internal quality; (2) Responsibility for external quality assurance guided by Education Accreditation Institutions of regional Universities or Vietnam Association of Colleges and Universities. Educational accreditation carries out according to a set of standards decided and promulgated by competent state agencies authority (VLL, 2017).

\section{+ The operation of accreditation:}

In the US: Steps to carry out accreditation include (Eaton, 2006): (1) Educational Institutions prepares a summary of its activities, based on specified general standards; (2) Inviting lecturers and administrative staff from other educational institutions to peer review after completing the self-assessment; (3) Accreditation organizations visit an institution for an official evaluation of institution's educational activities or training program; (4) Evaluation units that issue decisions to recognize or refuse accreditation results for the educational institution; (5) Periodically, educational institutions must continue external evaluated after improvements and continual adjustment of its educational activities.

In Vietnam, the accreditation process goes through the following steps (VLL, 2017): 
- Higher education institution self-assessment (internal evaluation) and publish the internal self-assessment report at least within 20 working days.

- Educational institutions send self-assessment reports and relevant documents to quality accreditation organizations for assessment. Within 20 working days, and accreditation organization evaluates and returns the results.

- External evaluation steps: (1) Research self-assessment records; (2) Preliminary survey at the educational institution; (3) Official survey at educational institutions; (4) Draft external evaluation report, send to the educational institution for consultation (within 15 days); (5) Within 15 working days, the external evaluation team notifies the educational institution; (6) Within 6 months, the accreditation institution holds a meeting with the education quality accreditation council to evaluate the accreditation results; (7) Within 10 working days, the quality accreditation organization shall send to the education institution a resolution on evaluation results; (8) The educational quality accreditation institution issues a decision and issues an education quality accreditation certificate; (9) Publicly announce the accreditation certificate on the website of the educational institution within 10 working days after it is granted; (10) Send to the management bodies about accreditation results.

- The validity period of accreditation certificate: At the time of 2.5 years after being accredited, the educational institution shall register and conduct a mid-cycle review. After five years, conducting an assessment of the next accreditation cycle. In the case of management, units detect fraud in the accreditation process, or the educational institution no longer responds to the requirements of the evaluation criteria, it may request to withdraw the accreditation certificate.

\section{+ Accrediting bodies:}

In the US, there are four of accreditation bodies types: (1) Regional accreditation bodies; (2) Faith-based accreditation bodies (mainly nonprofit and degree-granting); (3) Private accreditation bodies: they accredit mainly for-profit and based on career; (4) and there are sixty-two training program accreditation bodies in the US (Eaton, 2006).

In that, regional accreditation is the educational accreditation of schools, colleges, and universities in the US by one of seven regional accrediting agencies. Each local accreditation institution oversees the vast majority of public and private educational organizations, both not-for-profit and for-profit. Their primary function is the accreditation of postsecondary institutions, though there is a limited amount of accreditation of primary and secondary schools (Catherine, 2006), (Janice, 2003). Local accreditation is older than national accreditation and, several issues, more careful than national accreditation. Additionally, most nonprofit institutions are regionally accredited, while most for-profit colleges and universities are nationally accredited (Lechuga \& Vicente, 2005).

Have seven active regional accrediting organizations for educational institutions in the US (Regionally Accredited Colleges/Universities, 2011):

(1) Middle States Commission on Higher Education, formerly part of the Middle States Association of Colleges and Schools - Postsecondary organizations in New York, New Jersey, Pennsylvania, Delaware, Maryland, the District of Columbia, Puerto Rico, and the US Virgin Islands.

(2) New England Association of Schools and Colleges - Educational institutions in the six New England states (Connecticut, Maine, Massachusetts, New Hampshire, Rhode Island, and Vermont).

(3) Higher Learning Commission, formerly part of the North Central Association of Colleges and Schools Educational institutions in Arkansas, Arizona, Colorado, Iowa, Illinois, Indiana, Kansas, Michigan, Minnesota, Missouri, North Dakota, Nebraska, New Mexico, Ohio, Oklahoma, South Dakota, Wisconsin, West Virginia, and Wyoming.

(4) Northwest Commission on Colleges and Universities (NWCCU) for postsecondary institutions in Alaska, Idaho, Montana, Nevada, Oregon, Utah, and Washington.

(5) Southern Association of Colleges and Schools - Educational institutions in Alabama, Florida, Georgia, Kentucky, Louisiana, Mississippi, North Carolina, South Carolina, Tennessee, Texas, and Virginia.

(6) Accrediting Commission for Schools, Western Association of Schools and Colleges - 4-year educational institutions in California, Hawaii, Guam, American Samoa, Micronesia, Palau, and Northern Marianas Islands, as well as schools for American children in Asia.

(7) Accrediting Commission for Community and Junior Colleges, formerly part of the Western Association of Schools and Colleges - 2-year educational institutions in California, Hawaii, Guam, American Samoa, Micronesia, Palau, and Northern Marianas Islands, as well as schools for American children in Asia. 
In Vietnam, accreditation units in Vietnam include Education Accreditation Institutions of Universities, and accreditation organization of Association of Vietnam Universities and Colleges (AVU\&C) - an autonomous and independent organization with government management.

Current, there are five accrediting agencies for educational institutions in Vietnam (Nguyen, 2019):

(1) Center for Education Accreditation under the portfolio of the Association of Vietnam Universities and Colleges (CEA-AVU\&C).

(2) Education Accreditation Center, Viet Nam National University, Ha Noi (VNU-CEA).

(3) Center for Educational Quality Accreditation, National University, Ho Chi Minh City (VNU-HCM CEA).

(4) Center for Educational Quality Accreditation of the University of Danang (CEA.UD).

(5) Center for Educational Quality Accreditation of Vinh University (VCEA).

+ Recognition:

In the US, two agencies approve accreditation results as the US Department of Education and Council for Higher Education Accreditation (CHEA) - a nongovernmental, private, nonprofit organization for higher education institutions in the US (Koenig et al. 2004).

In Vietnam, institutions that review and approve educational accreditation units, including (Nguyen et al. 2019):

- AVU\&C decides to establish, then the Ministry of Education and Training (MOET) recognizes and licenses the operation: The Centre for Education Accreditation (CEA-AVU\&C).

- MOET decides to establish and licenses activities, including (1) The Education Accreditation Center, Viet Nam National University, Ha Noi (VNU-CEA); (2) Center for Educational Quality Accreditation, National University, Ho Chi Minh City (VNU-HCM CEA); (3) Center for Educational Quality Accreditation of the University of Danang (CEA.UD); (4) Center for Educational Quality Accreditation of Vinh University (VCEA).

Another difference, except for the CEA-AVU\&C, the remaining four centers of quality accreditation are under the national and regional universities.

\section{+ Basis of evaluation}

The general standards of regional accrediting bodies of the US include (Koenig, A. et al. 2004): (1) Have a mission and purpose are appropriate to higher education; (2) There are goals based on the task of the organization; (3) There are clearly defined financial, organizational and academic resources; (4) There is the system of continuous evaluation of progress toward the mission, goals, and make plans for future.

In Vietnam, accrediting organizations use the same set of standards and general criteria: (1) Accreditation institutions in Vietnam have a mission and aims agreement to higher education; (2) Have goals that based on the institutional mission; (3) Have clearly defined, function systems and resources - finance, agencies, and academic, to support the mission and vision and enable to realize; (4) Have a system of continuous evaluation of progress toward mission, goals, and planning for future development.

\section{+ The significance of accreditation}

In the US: Quality accreditation is aimed: (1) Ensuring employer units receive well-trained employees; (2) Protecting students from substandard competitors for admission or work, or entering unqualified institutions; (3) Guaranteed grants are not for under-qualified students, or the program doesn't meet the standard (Koenig et al. 2004).

In Vietnam: Quality accreditation is aimed at ensuring the rights of learners. Carrying out accountability for stakeholders include learners, lecturers, staff, leadership and management, employers, learners' families, investors, management agencies, other relevant organizations individuals, on quality, and operational efficiency of educational institutions.

\section{+ Fund resources}

In the US: Accreditation institutions are funded by (1) Fees are received from accreditation activities for educational organizations or training programs; (2) Fees due to institutions and programs pay for accreditation visits; (3) Funds received from sponsors; (4) Accreditation organizations sometimes received funds from the government or private foundations (Eaton, 2006).

In Vietnam, accreditation organizations in Vietnam (VLL, 2020):

- For the accreditation centers of national and regional universities: (1) Partially paid by the government, as the organizations are state administrative and non-business units; (2) Fees are received from accreditation activities for 
educational organizations or training programs; (3) Fees due to institutions and programs pay for accreditation visits; (4) Funds received from sponsors.

- For CEA-AVU\&C: Completely self-financing for all activities with the revenue from (1) Fees are received from accreditation activities for educational organizations or training programs; (2) Fees due to institutions and programs pay for accreditation visits; (3) Funds received from sponsors.

\section{Conclusions}

Accreditation is considered as one of the solutions to maintain and improve quality in higher education institutions. With an accredited higher education institution, learners have the assurance of receiving a good quality education, gaining recognition by labor markets, or other universities for their course credits or degrees. Accreditation is an affirmation that a university provides an education quality that society expects.

External quality assurance frameworks varied according to policies and perspectives of the US and Vietnam, however, generally are organized in three ways: First, Quality accreditation model managed by the state, for example, MOET in Vietnam; Second, a model of quality assurance combining between state management with the market competition; and the third, is model of quality assurance due to self-accrediting universities (Nguyen, 2019).

In the US, after World War II, higher education rapidly expanded, the federal Congress has applied a market-based approach to academic quality assurance as a supplement to the existing tradition of state licensing and voluntary institutional as well as program accreditation. During the 1972 re-authorization of the Higher Education Act, members of Congress argued that providing federal financial assistance directly to students rather than to institutions was the most efficient to both equalize opportunities in higher education and harness market forces for enhancing academic quality (Dill, 2007).

Differences between the US and Vietnam models shown in the following characteristics: the US model mainly to determine whether a higher education institution is worthy of continuing to function as an educational and training entity. While in Vietnam, quality accreditation results often results are used for quality improvement in educational institutions. In the Vietnam model, MOET decides to establish and licenses activities for all education accreditation centers. As a result, most of Vietnam's quality accreditation centers receive a portion of funding for actions from the government, are not independent, and no full autonomy, except CEA-AVU\&C. Thus, the Vietnam model has a point different from that of the US model is the quality accreditation centers of Vietnam still depend on the MOET or regional Universities, i.e. depends on the Government.

\section{Acknowledgment}

The author, Nguyen Duc Hanh, would like to thank Dai Nam University, Hanoi, Vietnam, for support to complete this research.

\section{References}

Catherine, F. (2006). Aligning Information Technology with Academic Standards, Educause Center for Applied Research Research Bulletin, 10. "Regional acceditors include among their membership nearly all community colleges and public and private colleges universities in the region that they serve."

Dill, D. (2007). Quality Assurance in Higher Education: Practices and Issues. In B. McGaw, E. Baker \& P. P. Peterson (Eds.), The 3rd International Encyclopedia of Education. Oxford: Elsevier.

Eaton, E. (2003). Is Accreditation Accountable? The Continuing Conversation Between Accreditation and the Federal Government. Council for Higher Education Accreditation, CHEA Monograph Series 2003, No(1), 3.

Eaton, J. (2006). Accreditation and Recognition in the United States, Council for Higher Education Accreditation CHEA. Washington DC, USA.

Hämäläinen, K., Haakstad, J., Kangasniemi, J., Lindeberg, T., \& Sjölund, M. (2001). Quality assurance in the Nordic higher education. Helsinki: ENQA Occasional Papers, 2.

Hanh, N. D. (2019). Review Some Issues of Quality Assurance, Quality Accreditation for Higher Education Institutions and Reality of Vietnam. American Journal of Educational Research, 7(7), 524-529.

Hanh, N. D., Nga, N. T. M., Loan, V. Q., \& Viet, N. M. (2019). Role of Quality Assurance and Quality Accreditation in Higher Education in Some Developing Countries and Vietnam. American Journal of Educational Research, 7(9), 649-653.

Karlen, J. M. (2003). Accreditation and assessment in distance learning. Academic Leadership: The Online Journal, $1(4), 3$. 
Koenig, A., Lofstad, R., \& Staab, E. (2004). Higher Education Accreditation in the United States: What International Education Professionals Need to Know. EAIE Conference, Torino, Italy, 18.

Kymlicka, W., \& Patten, A. (eds.). (2003). Language Rights and Political Theory. Oxford: Oxford University Press. https://doi.org/10.1017/S0267190503000163

Lechuga, V. M. (2006). The changing landscape of the academic profession. Taylor \& Francis. https://doi.org/10.4324/9780203959930

Parekh, B. (2000). Rethinking Multiculturalism: Cultural Diversity and Political Theory, Cambridge, MA: Harvard University Press.

Regionally Accredited Colleges/Universities. (2011). Retrieved from https://web.archive.org/web/20100831235144/ http://www.k12.wa.us/certification/colleges/reg_accred.html

Van Damme, D. (2002). Trends and models in international quality assurance and accreditation in higher education in relation to trade in education services. Quality Assurance, May. https://doi.org/10.1787/hemp-v14-art21-en

Vietnam law library. (2005). Education Law 2005. Retrieved from https://thuvienphapluat.vn/van-ban/giao-duc/Luat-Giao-duc-2005-38-2005-QH11-2636.aspx

Vietnam law library. (2017). Circular 12. Retrieved from https://thuvienphapluat.vn/van-ban/giao-duc/Thong-tu-12-2017-TT-BGDDT-kiem-dinh-chat -luong-co-so-giao-duc-dai-hoc-349575.aspx

Vietnam law library. (2020). Decision $38 . \quad$ Retrieved from https://thuvienphapluat.vn/van-ban/giao-duc/Quyet-dinh-38-2004-QD-BGDDT-kiem-dinh-chat-luong-truong-dai-h oc-20735.aspx

Western Association of Schools and Colleges. (2001). Accrediting Commission for Senior Colleges and Universities, Handbook of Accreditation. Alameda, CA. USA.

\section{Copyrights}

Copyright for this article is retained by the author(s), with first publication rights granted to the journal.

This is an open-access article distributed under the terms and conditions of the Creative Commons Attribution license (http://creativecommons.org/licenses/by/4.0/). 